\title{
Effectiveness of Learning Strategy and Learning Style on Learning Outcomes
}

\author{
Chirsant Florence Lotulung, Nurdin Ibrahim, Hetty Tumurang \\ \{chrisantflorence_tp10s3@mahasiswa.unj.ac.id,nurdinibrahim@gmail.com, \\ hettytumurang@gmail.com \} \\ Universitas Negeri Jakarta ${ }^{1,2}$, Universitas Negeri Manado ${ }^{3}$
}

\begin{abstract}
The purpose of this study was to determine the effect of learning strategies and learning styles on learning outcomes of Entrepreneurship courses. This research uses quasi-experimental method (quasi experimental) with factorial design. The results of the study: (1) Student entrepreneurship learning outcomes learned by CTL learning strategies are higher than student learning outcomes that are taught by conventional learning strategies, (2) Entrepreneurship learning outcomes between students who have a visual learning style higher than student learning outcomes who have auditorial learning style, (3) There is an interaction effect between learning strategies and learning styles on student learning outcomes in entrepreneurship courses.
\end{abstract}

Keywords: learning strategic, learning style, learning outcomes

\section{Introduction}

Learning is a process which occupies an important role in moulding the structure of our personality and behaviour. It develops socially accepted behaviours and also there is equal chance of building negative side of human behaviour (Darmaraj, 2015). Learning is defined as a deliberate effort by educators to support student learning activities (Kusumandari \& Istyarini, 2015). Choosing the right learning strategy will greatly affect the achievement of the learning objectives that have been set. As stated by Youngqi Gu (2017) that learning strategy is a prototypical rather than categorical concept, and finding a prototypical core and mapping out dimensions of variation would be a practical solution. Instructional strategies are techniques teachers use to help students become independent, strategic learners. These strategies become learning strategies when students independently select the appropriate ones and use them effectively to accomplish tasks or meet goals (Anom, 2002).

The use of the right teaching strategy is very important to note, therefore the teaching strategy used must also be able to foster attraction for the learner. Besides learning strategies, learning styles and learning strategies determine the learning outcomes of students.

\section{Method}

The method used in this study is an experimental strategy using a quasi-experimental strategy approach. Campbell and Stanley (2007) refer to experiments that lack random assignment as quasi-experiments. This type of experimental design is a development of 
experimental design that is difficult to implement. This study used an experimental strategy with design factorial $2 \times 2$. To get a belief that the research design used is good for testing the research hypothesis and the results obtained can be generalized to the study population. The purpose of the research design is to provide answers to credible research questions, showing reality. There are two concepts used to explain the level of trust as a result of learning in experimental research, namely internal validity and external validity.

\section{Result}

The data that has been collected in this study is data on learning outcomes. Furthermore, the collected data is first described so that it is easy to understand. The data was divided into eight groups, namely (1) groups of students who were taught with CTL learning strategies, (2) groups of students who had visual learning styles, (3) groups of students who had auditory learning styles, (4) groups of students who received treatment strategies CTL learning with visual learning styles, (5) groups of students who get the CTL learning strategy treatment with students who have auditory learning styles. Description of groups of learning outcomes data on Entrepreneurship courses as a whole are presented in the following table 1:

TABLE 1. DESCRIPTION DATA OF LEARNING OUTCOMES AND LEARNING STRATEGY

\begin{tabular}{|c|c|c|c|c|c|c|}
\hline \multirow{3}{*}{$\begin{array}{c}\text { Learning } \\
\text { Style }\end{array}$} & \multicolumn{4}{|c|}{ Learning Strategic } & \multirow{2}{*}{\multicolumn{2}{|c|}{ Account of Line }} \\
\hline & \multirow{2}{*}{\multicolumn{2}{|c|}{$\begin{array}{c}\text { CTL } \\
A_{1}\end{array}$}} & \multirow{2}{*}{\multicolumn{2}{|c|}{$\begin{array}{c}\text { Konvensional } \\
\mathrm{A}_{2}\end{array}$}} & & \\
\hline & & & & & & \\
\hline \multirow{5}{*}{ Visual (B1) } & $\mathrm{N}$ & 14 & $\mathrm{~N}$ & 14 & $\mathrm{n}_{\mathrm{B} 1}$ & 28 \\
\hline & $\sum x$ & 327 & $\sum x$ & 255 & $\sum x$ & 582 \\
\hline & $\sum x^{2}$ & 7875 & $\sum x^{2}$ & 4747 & $\sum x^{2}$ & 12622 \\
\hline & $\mathrm{s}^{2}$ & 18,25 & $\mathrm{~s}^{2}$ & 7,87 & $\mathrm{~s}^{2}$ & 19,43 \\
\hline & $\bar{x}$ & 23,36 & $\bar{x}$ & 18,21 & $\bar{x}$ & 20,79 \\
\hline \multirow{5}{*}{$\begin{array}{l}\text { Audytorial } \\
\text { (B2) }\end{array}$} & $\mathrm{N}$ & 14 & $\mathrm{~N}$ & 14 & $\mathrm{n}_{\mathrm{B} 2}$ & 28 \\
\hline & $\sum x$ & 264 & $\sum x$ & 247 & $\sum x$ & 511 \\
\hline & $\sum x^{2}$ & 5130 & $\sum x^{2}$ & 4491 & $\sum x^{2}$ & 9621 \\
\hline & $\mathrm{s}^{2}$ & 11,67 & $\mathrm{~s}^{2}$ & 10,25 & $\mathrm{~s}^{2}$ & 10,94 \\
\hline & $\bar{x}$ & 18,86 & $\bar{x}$ & 17,64 & $\bar{x}$ & 18,23 \\
\hline \multirow{5}{*}{$\begin{array}{l}\text { Account of } \\
\text { Coloum }\end{array}$} & $\mathrm{n}_{\mathrm{A} 1}$ & 28 & $\mathrm{n}_{\mathrm{A} 2}$ & 28 & & 56 \\
\hline & $\sum x$ & 591 & $\sum x$ & 502 & $\sum x$ & 1093 \\
\hline & $\sum x^{2}$ & 13005 & $\sum x^{2}$ & 9238 & $\sum x^{2}$ & 22243 \\
\hline & $\mathrm{s}^{2}$ & 19,66 & $\mathrm{~s}^{2}$ & 8,81 & $\mathrm{~s}^{2}$ & 16,55 \\
\hline & $\bar{x}$ & 21,11 & $\bar{x}$ & 17,93 & $\bar{x}$ & 19,52 \\
\hline
\end{tabular}

Normality test is one of the prerequisites for data analysis. The normality test is done to find out whether the study population is normally distributed or not. The normality test aims to determine whether the collected data follows the normal curve. The normality test was conducted for Entrepreneurship learning outcomes data, in eight data groups. The normality test for each group in this study used the Liliefors Test. The following is a summary of the results of the normality test for eight data groups as follows: 
TABLE 2. SUMMARY OF DATA NORMALITY TEST

\begin{tabular}{|c|c|c|c|c|c|}
\hline No & Data Group & $\mathbf{N}$ & $\mathbf{L}_{\text {account }}$ & Ltable & Decision \\
\hline 1 & $\begin{array}{l}\text { The student group taught with the } \\
\text { CTL strategy }\left(A_{1}\right)\end{array}$ & 14 & 0,400 & 0,997 & Norm \\
\hline 2 & $\begin{array}{l}\text { Student groups taught with } \\
\text { conventional strategies (A2) }\end{array}$ & 14 & 0,746 & 0,634 & Norm \\
\hline 3 & $\begin{array}{l}\text { Student group with visual learning } \\
\text { style (B1) }\end{array}$ & 14 & 0,653 & 0,787 & Norm \\
\hline 4 & $\begin{array}{l}\text { Student groups with auditory } \\
\text { learning styles (B2) }\end{array}$ & 14 & 0,596 & 0,869 & Norm \\
\hline 5 & $\begin{array}{l}\text { Student groups using CTL } \\
\text { learning with visual learning } \\
\text { styles (A1B1) }\end{array}$ & 28 & 0,491 & 0,969 & Norm \\
\hline 6 & $\begin{array}{l}\text { Group of students using CTL } \\
\text { learning with auditorial learning } \\
\text { styles (A1B2) }\end{array}$ & 28 & 0,431 & 0,992 & Norm \\
\hline 7 & $\begin{array}{l}\text { Student groups using CTL } \\
\text { learning with visual learning } \\
\text { styles (A2B1) }\end{array}$ & 28 & 0,680 & 0,744 & Norm \\
\hline 8 & $\begin{array}{lrr}\text { Student } & \text { groups } & \text { using } \\
\text { conventional } & \text { learning } & \text { with } \\
\text { auditory learning styles (A2B2) }\end{array}$ & 28 & 0,504 & 0,961 & Norm \\
\hline
\end{tabular}

Homogeneity tests were conducted to prove that the data obtained from the results of the study were in the form of student learning outcomes (initial tests and final tests) in the second. The homogeneity test for the collected data is done using Barlett's Test with a significance level of 5\%. Homogeneity variance test was carried out on three groups of data. The homogeneity of groups A1B1, A1B2, A2B1, A1B2 was tested using the Barletts test with a significance level of $5 \%$. A summary of homogeneity calculations is presented in the following table 3 .

TABLE. 3 SUMMARY OF CALCULATIONS OF GROUP HOMOGENEITY TESTS FOR A1B1, A1B2, A2B1, A1B2

\begin{tabular}{|c|c|c|c|c|c|c|c|}
\hline Group & $\mathrm{Db}$ & $\mathbf{s}^{2}$ & $\log s^{2}$ & $\begin{array}{c}\mathrm{db} \log \\
\mathrm{s}^{2}\end{array}$ & $\mathbf{S}^{2}$ gab & B & $\mathbf{X}^{2}$ hit \\
\hline $\mathrm{A}_{1} \mathrm{~B}_{1}$ & 28 & 4,75 & 0,677 & 12,863 & \multirow{4}{*}{9,273} & \multirow{4}{*}{73,509} & \multirow{4}{*}{4,677} \\
\hline $\mathrm{A}_{1} \mathrm{~B}_{2}$ & 28 & 13,05 & 1,116 & 21,204 & & & \\
\hline $\mathrm{A}_{2} \mathrm{~B}_{1}$ & 28 & 9,43 & 0,975 & 18,525 & & & \\
\hline$A_{1} B_{2}$ & 28 & 9,86 & 0,994 & 18,885 & & & \\
\hline Total & 112 & 37,09 & 3,76 & 71,478 & & & \\
\hline
\end{tabular}

Based on the table above, the results of calculation of homogeneity test in the experimental group obtained $\mathrm{x} 2$ count $=0.4677$ and $\mathrm{x} 2$ table $=7.81$. Thus because $\mathrm{x} 2$ count $=0.4677$ and $\mathrm{x} 2$ table $=7.81$ then Ho is accepted. This shows that the data from both groups have homogeneous variances where the value of $\mathrm{x} 2$ counts $<\mathrm{x} 2$ tables.

The homogeneity of groups A1 and A2 were tested using the Barletts test with a significance level of 5\%. The testing criteria is Ho accepted if Fcount <FTabel. A summary of the calculation of homogeneity of groups A1 and A2 is presented in the following table 4.

TABLE. 4 SUMMARY OF CALCULATION OF HOMOGENEITY TEST FOR GROUP A1 AND A2 GROUP

\begin{tabular}{|c|c|c|c|c|c|c|c|}
\hline Group & $\mathrm{Db}$ & $s^{2}$ & $\log s^{2}$ & $\begin{array}{c}\mathrm{db} \log \\
\mathbf{s}^{2}\end{array}$ & $\mathbf{S}_{\text {gab }}^{2}$ & B & $\mathbf{X}^{2}$ hit \\
\hline$A_{1} B_{1}$ & 28 & 4,75 & 0,677 & 12,863 & \multirow{4}{*}{9,273} & \multirow{4}{*}{73,509} & \multirow{5}{*}{4,677} \\
\hline $\mathrm{A}_{1} \mathrm{~B}_{2}$ & 28 & 13,05 & 1,116 & 21,204 & & & \\
\hline $\mathrm{A}_{2} \mathrm{~B}_{1}$ & 28 & 9,43 & 0,975 & 18,525 & & & \\
\hline$A_{1} B_{2}$ & 28 & 9,86 & 0,994 & 18,885 & & & \\
\hline Total & 112 & 37,09 & 3,76 & 71,478 & & & \\
\hline
\end{tabular}


Based on the results of the analysis, it can be concluded: (1) Differences in learning outcomes of student entrepreneurship courses taught with CTL learning strategies and conventional learning strategies, (2) Differences in learning outcomes of entrepreneurial courses of students who have visual learning styles and students who have auditory learning styles , (3) Effect of learning strategy interactions with learning styles on learning outcomes of entrepreneurship courses, (4) Differences in learning outcomes of entrepreneurial courses of students who have a visual learning style and are taught with CTL learning strategies with students who are taught with conventional learning strategies, (5) Differences in learning outcomes of entrepreneurial courses of students who have auditory learning styles and are taught with CTL learning strategies with students who are taught with conventional strategies, (6) Differences in learning outcomes of student entrepreneurship courses taught by students bro, the CTL learning strategy is between students who have visual learning styles and students who have auditory learning styles, and (7) Differences in learning outcomes of student entrepreneurship courses taught with conventional learning strategies between students who have a visual learning style and students have auditory learning styles.

Based on the results of the analysis the researcher will discuss the results of hypothesis testing based on the theory and or the results of relevant research to describe whether the results of the research obtained can support or not to the relevant theory or research. First, the testing of the first hypothesis shows that student learning outcomes in Entrepreneurship courses that are taught by CTL learning strategies are higher compared to student learning outcomes in Entrepreneurship courses that are taught by conventional strategies. Thus there is the influence of the use of learning strategies on student learning outcomes in Entrepreneurship courses. Second, the results of testing the second hypothesis show that there is an interaction between learning strategies and learning styles towards learning outcomes in Entrepreneurship courses. That the use of learning strategies has an influence on student learning outcomes. Learning strategies greatly affect the learning process. Selection The right learning strategy will be fun and not make students bored. Third, the third hypothesis testing shows that the learning outcomes of Entrepreneurship courses taught with CTL learning strategies are higher than the student learning outcomes taught with conventional learning strategies, for students who have a visual learning style. Fourth, in testing the fourth hypothesis Ho is accepted. This shows that there is no difference in entrepreneurial learning outcomes of students who have visual learning styles and auditory learning styles. Learning outcomes are some of the results achieved by students after experiencing the learning process. The learning process activities in schools are intended to obtain good learning outcomes. Fifth, the entrepreneurship learning outcomes of students who are taught with CTL learning strategies and have auditory learning styles are lower than those taught with conventional learning strategies. Learning outcomes are statements about what is expected, known and / or can be demonstrated by students after completing a learning process. Sixth, the entrepreneurial learning outcomes of students who are taught with CTL learning strategies and have a visual learning style are higher than students who have auditory learning styles. Seventh, the entrepreneurial learning outcomes of students who are taught with conventional learning strategies and have visual learning styles are lower than students who have auditory learning styles

\section{Conclusion}

Conclusions that can be drawn from the results of analysis and discussion show that: (1) Student learning outcomes in Entrepreneurship courses with CTL learning strategies are higher compared to student learning outcomes in Entrepreneurship courses with Conventional learning 
strategies, (2) Student learning outcomes in the eyes Entrepreneurship courses for students with visual learning styles are higher than the learning outcomes of student entrepreneurship courses with auditory learning styles, (3) There is an interaction effect between learning strategies and learning styles on Entrepreneurship learning outcomes, (4) Student learning outcomes in student Entrepreneurship courses which is subject to CTL learning strategies with a visual learning style higher than the learning outcomes of student Entrepreneurship courses subject to CTL learning strategies with auditory learning styles, (5) Student learning outcomes in student Entrepreneurship courses are subject to conventional learning strategies with a visual learning style higher than the learning outcomes of student Entrepreneurship courses subject to conventional learning strategies with auditory learning styles, (6) Student learning outcomes in student Entrepreneurship courses subject to CTL learning strategies with more visual learning styles high compared to the learning outcomes of student Entrepreneurship courses subject to conventional learning strategies; and (7) student learning outcomes in Entrepreneurship courses of students subject to conventional learning strategies with auditory learning styles higher than the learning outcomes of student Entrepreneurship courses subject to learning strategies conventional.

\section{Acknowledgment}

Acknowledgments the researcher conveyed to the UNJ which gave the opportunity for researchers to obtain the Doctoral Dissertation Research.

\section{References}

[1] Anom, 2002, Instructional Strategies. Health and Life Skills Guide to Implementation (K-9), Canada: Alberta

[2] Azmahani A. Aziz, Khairiyah M Yusof, \& Jamaludin M. Yatim, Evaluation on the Effectiveness of Learning Outcomes from Students' Perspectives, Procedia - Social and Behavioral Sciences 56 ( 2012 ) 22 - 30, h.23

[3] Bjerke, Bjorn \& Ramo, Hans, 2011, Entrepreneurial Imagination : Time, Timing, Space and Place in Bussiness Action, UK: Edwar Elgar

[4] Byun, Chung-Gyu et.al. A Study on the Effectiveness of Entrepreneurship Education Programs in Higher Education Institutions: A Case Study of Korean Graduate Programs, J. Open Innov. Technol. Mark. Complex. 2018, 4, 26; doi:10.3390/joitmc4030026

[5] Campbell, D.T., \& Stanley, J.C., 2007, dikutip dalam Meredith D. Gail, Joyce P.Gall, Walter R. Borg, Educational Research: an Introduction, $8^{\text {th }}$ edition Boston: Pearson Education, Inc

[6] Dharmaraj, William, 2015, Learning and Teaching, Thailand: Centre For Distance Education'

[7] Gedeon, Steven, 2017, Measuring Student Transformation in Entrepreneurship Education Programs, Education Research International Volume 2017, Article ID 8475460, 12 pages

[8] Grebel, 2004, Entrepreneurship A New Prespective, London: Routledge

[9] Hakan, Karatas. Balyer Aydin \& Alci Bulent, An Investigation Of Undergraduates' Language Learning Strategies, Procedia - Social and Behavioral Sciences 197 ( 2015) 1348 - 1354, h.1348

[10] Keister, Lisa A, 2005, Research in The Sociology of Work Volume 15 : Entrepreneurship, London: Elsevier

[11] Kennedy, Declan, 2007, Writing and Using Learning Outcomes A Practical Guide, Chicago: Quality Promotion Unit, UCC

[12] Kist, AA. \& Lyn Brodie, Mapping Learning Outcome and Assignment Tasks for SPIDER Activities, iJET Volume 6, Special Issue 2: "EDUCON2011", May 2011, h.25

[13] Kusumandari, Rafika Bayu \& Istyarini, Character Education Development Model-based E-Learning and Multiple Intelegency in Childhood in Central Java, Global Journal of Computer Science and Technology: H Information \& Technology Volume 15 Issue 3 Version 1.0 Year 2015

[14] Mcdonald, 2014, The Nurse Educator's Guide to Assesing Learning Outcomes, Third Edition. USA: Jones \& Barlett Learning 
[15] Nygaard, Claus. Clive Holtham, Nigel Courtney, 2009, Improving Student's Learning Outcomes, Denmark: Copenhagen Business School Press

[16] Peculea, Lorena \& Bocos, Musata. The Role of Learning Strategies in the Development of the Learning-to-learn Competency of 11th Graders from Technical Schools, Procedia-Social and Behavioral Sciences 203 (2015) 16 -21, h. 17

[17] Riding, Richard J. \& Rayner, Stephen G. , 2007 Cognitive Styles and Learning Strategies: Understanding Style Differences In Learning And Behaviour, Canada: Routledge

[18] Stokes, David. Nicholas Wilson, Martha Mador, 2010 Enterpreneurhip, UK: Thomas Tennie

[19] Taurina, Zane, Students' Motivation and Learning Outcomes: Significant Factors in Internal Study Quality Assurance System, International Journal for Cross-Disciplinary Subjects in Education (IJCDSE), Special Issue Volume 5 Issue 4, 2015

[20] Youngqi Gu, 2002, Learning Strategies : Prototypical Core and Dimensions of Variation. Studies in Self-Access Learning Journal, 3 (4), 330-356, h.331 